\title{
Development of a Business Plan for an Integrated Light Pole Wind Turbine System in Puerto Rico
}

\author{
Jannette Pérez-Barbosa, MS ${ }^{1}$, Héctor Martínez-Rosa, BSIE ${ }^{2}$, and Pedro Rodríguez-Ocasio, BSIE ${ }^{3}$ \\ ${ }^{1}$ Universidad Ana G. Méndez, Gurabo Campus, Puerto Rico, jperez222@uagm.edu \\ ${ }^{2}$ Universidad Ana G. Méndez, Gurabo Campus, Puerto Rico, hectord45@ hotmail.com \\ ${ }^{3}$ Universidad Ana G. Méndez, Gurabo Campus, Puerto Rico, pedroj457@ hotmail.com.com
}

\begin{abstract}
A university team worked on a new product development to reduce the energy costs associated with public illumination. The research deliverables include the development of a business plan that proposes a substitution of the current energy source with an eolic alternative. The proposed application could result in savings of approximately $\$ 100$ million annually. Topics within the research include application and market identification, evaluation of alternatives and risk analysis. Keywords- energy management, wind energy, business plan, renewable energy.
\end{abstract}

\section{INTRODUCTION}

Puerto Rico (PR) has experienced an economic recession for the past decade. The high cost of energy has a direct impact on citizens and businesses, becoming a significant burden for economic development. In addition, the aftermath of Hurricane Maria left the island with additional infrastructure and economic hardships that after almost two years have not been solved. In order to increase the quality of life of the residents, renewable energy can become a feasible and cost-effective alternative for everyday applications.

According to the Puerto Rico Electric Power Authority (PREPA), $47 \%$ of the electricity in PR is produced by oil burning plants. Natural gas and coal represent $34 \%$ and $17 \%$ of production, respectively. Only $2 \%$ of the electricity is being produced by renewable sources [1]. An existing state law requires that at least $15 \%$ of the energy produced must be generated through renewable sources by 2020 [2], increasing to $20 \%$ by 2035 . With $2 \%$ of electricity currently produced by renewable sources, meeting the requirements of this law has become a daunting task.

Banuchi [3] computed the annual energy costs for municipal public illumination in $\$ 109.1$ million (43\% of total energy spending). This spending is allocated to the municipalities through the Contribution in Lieu of Taxes (CILT). The CILT exempts the municipalities from paying these bills, creating debts to PREPA which are recovered through an $11 \%$ mark-up on the oil and other fuels to its residential and commercial customers [4]. The use of renewable energy for public illumination can represent significant savings in energy cost.

After the impact of Hurricane María, the electrical infrastructure was severely damaged. Since the reconstruction of the power infrastructure is still ongoing, most light poles

Digital Object Identifier (DOI):

http://dx.doi.org/10.18687/LACCEI2020.1.1.19

ISBN: 978-958-52071-4-1 ISSN: 2414-6390 have not been repaired. As a result, traffic safety has become an issue, even on highways. Another effect is the increasing crime in streets and residences due to no illumination. The use of renewable energy will increase the quality of life for residents. Off grid public illumination would also be resilient to failures in the power generation and distribution infrastructure.

The U.S. Department of Energy (DOE) and the National Renewable Energy Laboratory (NREL) created the Collegiate Wind Competition in 2014. Juracán Energy Team (JET), from Universidad Ana G Mendez in Gurabo, Puerto Rico, is one of the teams in the competition. JET wishes to use wind energy sources as a viable alternative to reduce the dependence on fossil fuels to power public illumination. The idea is to create an alternative to generate electricity for public lighting without incurring in energy expenses with PREPA that can also function when power grid failures occur.

There are several renewable energy sources available worldwide. The Pareto chart in Fig 1 shows the 2017 energy output from renewable sources in the US [5]. The two major generation sources are the conventional hydroelectric and wind.

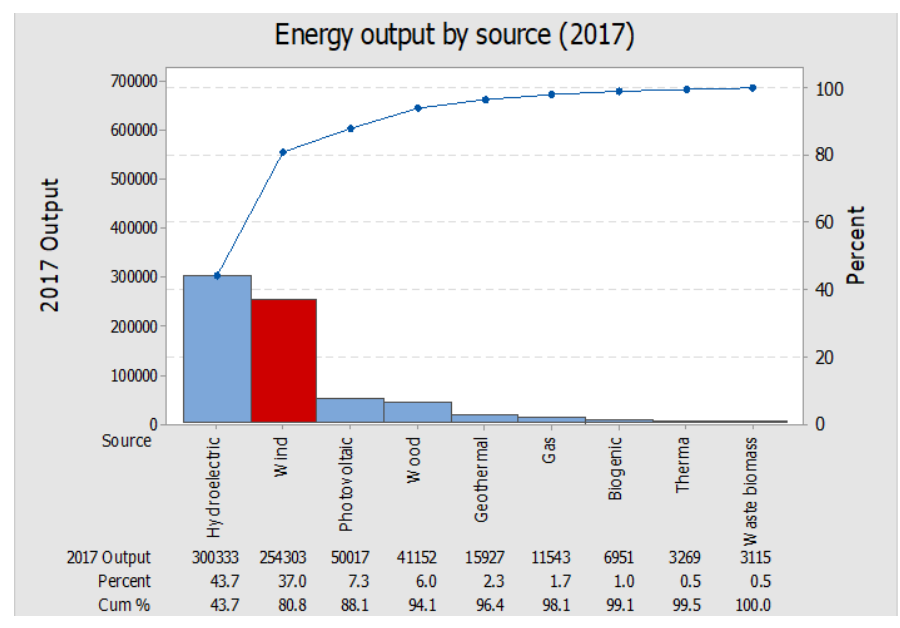

Fig. 1: Average annual energy output by source in the US (Thousand Megawatthours)

While hydroelectric energy has the largest electric output on the chart, it is outside of the focus of JET for the Collegiate Wind Competition. Eolic energy applications present great opportunities for reducing cost of public lightning but also for

$1^{\text {th }}$ LACCEI International Multi-Conference for Engineering, Education, and Technology: "Engineering, Integration, and Alliances for a Sustainable Development" "Hemispheric Cooperation for Competitiveness and Prosperity on a Knowledge-Based Economy", 27-31 July 2020, Virtual Edition. 
managing other small-scale necessities in case of power outages due to emergencies. The activities required to complete the business plan are presented in the next sections.

\section{BUSINESS PLAN}

JET wishes to power everyday energy applications using wind energy. As part of this agenda, it proposes the first comprehensive business plan to transform the current public lighting all around Puerto Rico, replacing fossil fuel power generation with wind energy.

For Mckeever [6], a business plan is a written statement that describes and analyzes a business and gives detailed projections about its future. It gives a clear course toward the future, in this case, the development of a business that can address the issue of public illumination costs and provide a cost-effective alternative that functions with eolic energy. There is an existing initiative that proposes renewable energy for public illumination, but using solar panels in each light pole [7]. This application is also innovative, but with a different scope than the research presented in this paper.

The application of eolic energy generation to street lighting pole is an innovative approach compared with other existing implementations of renewable energy on the island. Relevant sections in the plan include the Business Overview (mission, vision, values of the company and market opportunity), market identification as well as the proposed solution. These will give relevance, direction and sense of purpose to the business, and are shown next:

A. Vision - Company vision is to "Be an established company in the market of renewable energy. Recognized by changing the way of generating energy in the world, transforming the traditional energy model into a solid structure of renewable energy leader. Expand quality services to other regions. Our long-term goal is to develop other renewable energy applications that meet market demands".

This vision reflects the path that JET is pursuing through the company lifespan with the aspiration of doing businesses in many markets.

B. Mission - The mission of JET "Be the new leader of wind energy companies. Providing an innovative product through renewable energy. Our clients are our reason for being and we seek to reduce energy costs and contribute to environmental preservation".

This mission reflects JET as a company and its goal of promoting the potential of renewable energy. This goal can only be achieved with innovation and by understanding the customer requirements and translating these into an innovative design.
C. Identifying Strengths Weaknesses Opportunities and Threats (SWOT). JET expects to be competitive in the market for wind turbines of small scale by providing an alternative that improves public illumination by using renewable energy. An evaluation of the company's competitive position using SWOT is shown next.

\section{Strengths:}

a. Produce unique product in Puerto Rico with the benefit of being the first to use wind power integrated directly into a street lighting pole.

b. An investment is required to replace lights with LED and adapt turbines. Pole does not need replacement.

2. Weaknesses:

a. No manufacturing capabilities.

b. Production activities, supply chain and pricing structures are unknown at this moment.

3.Opportunities

a. Ability to generate electricity at low wind speeds. Relevant for a deployable application in all regions of Puerto Rico.

\section{Threats}

a. Many people still think technology is not affordable and payback period is too long.

Corrective actions that can be taken to increase competitive advantage include:

1. Ability to show significant savings.

2. Promoting the product as an innovative idea based on proven technology, using current studies, prototypes and other sources of information.

3. To achieve manufacturing capabilities potential solutions are contract manufacturing and developing production facilities. These will be included as next steps for future research.

\section{PROBLEM DEFINITION}

The island electricity consumption has been increasing at a small rate with energy cost slightly decreasing [1]. Fig.2 shows a no growth in the average yearly purchased electricity. 


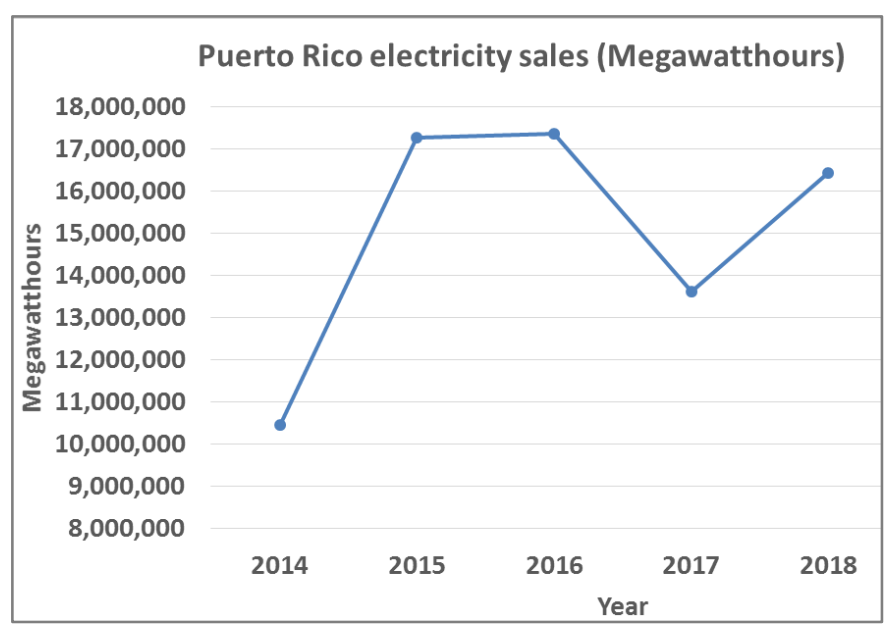

Fig. 2 Average annual electricity sales (Megawatthours)

Meanwhile, Fig. 3, does not show a significant increment in the electricity consumption during recent years. This is potentially due to decreases in population due to migration, which has increased due to the decade long economic crisis.

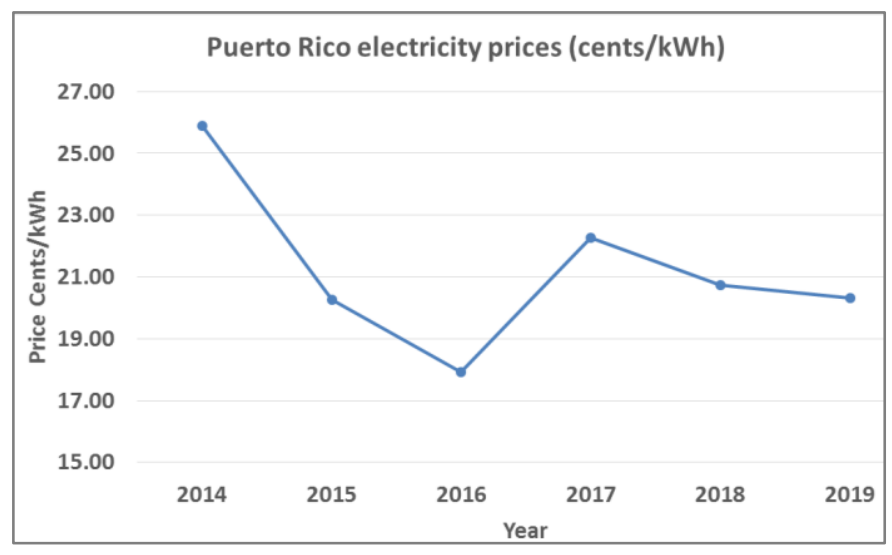

Fig. 3 Puerto Rico residential electricity prices

While energy costs are decreasing, an increase in energy cost is expected in the near future [8], as PREPA has recently made deals with some of its creditors to restructure. One of these deals totals 8 billion dollars and will end up increasing tariffs from 1 cent per $\mathrm{kWh}$ to 4.5 cent per $\mathrm{kWh}$ at the end of the 40 year deal.

\section{SOLUTION}

JET is following the systems engineering (SE) approach in the design of the proposed wind energy system. Pre-Phase A [9] begun with the evaluation of several off-grid wind energy applications that could be significantly impacted with the use of wind energy. Potential applications included camping/outdoors, food trucks, public lighting, and billboards for off grid wind applications. These applications and the decision process used are shown in Table 1.
The decision process included these dimensions:

1. Market potential

2. Scalability / Power Requirements

3. Technical innovation

4. Technical readiness

5. Cost

6. Manufacturability

7. Social / Environmental impact

The decision analysis recommended creating an application to power food trucks with eolic energy. This decision was reevaluated after meetings with the staff of the Office of Energy Affairs in Puerto Rico and other stakeholders, since the impact of renewable energy in public illumination was much significant. The large impact from this application will also result in gaining support from policy makers and other government stakeholders.

Table 1 Decision Matrix for application selection

\begin{tabular}{|c|c|c|c|c|c|}
\hline Concept & \multirow{4}{*}{ 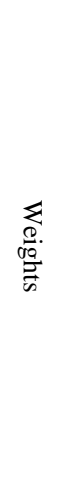 } & $\begin{array}{c}\text { Camping } \\
\text { or } \\
\text { outdoors } \\
\end{array}$ & $\begin{array}{l}\text { Food } \\
\text { trucks }\end{array}$ & $\begin{array}{l}\text { Illumi- } \\
\text { nation }\end{array}$ & $\begin{array}{l}\text { Build- } \\
\text { board }\end{array}$ \\
\hline $\begin{array}{l}\text { Load } \\
\text { (What is this } \\
\text { for?) }\end{array}$ & & $\begin{array}{c}\text { Basic } \\
\text { utilities }\end{array}$ & $\begin{array}{l}\text { Kitchen } \\
\text { equip- } \\
\text { ment }\end{array}$ & $\begin{array}{l}\text { Light } \\
\text { poles }\end{array}$ & LCD's \\
\hline $\begin{array}{c}\text { Power } \\
\text { requirements } \\
\text { (Range) }\end{array}$ & & $\begin{array}{c}500 \mathrm{~W}- \\
1 \mathrm{~kW}\end{array}$ & $\begin{array}{c}500 \mathrm{~W}- \\
1 \mathrm{~kW}\end{array}$ & $100 \mathrm{~W}$ & $\begin{array}{l}250 \mathrm{~W} \\
-1 \mathrm{~kW}\end{array}$ \\
\hline $\begin{array}{c}\text { Market } \\
\text { (Who will } \\
\text { purchase it?) }\end{array}$ & & 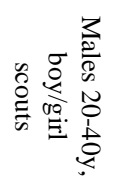 & $\begin{array}{l}T \\
0 \\
0 \\
0 \\
\vdots \\
\vdots \\
\frac{0}{6}\end{array}$ & 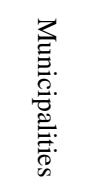 & 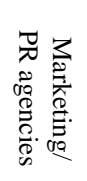 \\
\hline $\begin{array}{c}\text { Market } \\
\text { potential }\end{array}$ & $30 \%$ & 3 & 9 & 9 & 3 \\
\hline $\begin{array}{l}\text { Scalability / } \\
\text { Power } \\
\text { Requirements }\end{array}$ & $15 \%$ & 9 & 9 & 9 & 9 \\
\hline $\begin{array}{l}\text { Technical } \\
\text { innovation }\end{array}$ & $20 \%$ & 9 & 9 & 3 & 9 \\
\hline $\begin{array}{l}\text { Technical } \\
\text { readiness }\end{array}$ & $10 \%$ & 9 & 9 & 9 & 9 \\
\hline Cost & $10 \%$ & 1 & 3 & 1 & 9 \\
\hline Manufacturability & $5 \%$ & 9 & 9 & 9 & 3 \\
\hline $\begin{array}{c}\text { Social / } \\
\text { Environmental } \\
\text { impact } \\
\end{array}$ & $10 \%$ & 9 & 3 & 9 & 9 \\
\hline Total & & 6.4 & 7.8 & 7 & 6.9 \\
\hline
\end{tabular}

JET proposes the creation of grid independent wind turbines that can be adapted to existing light poles, reducing initial investment to the turbine and energy storage devices. The solution will also include LED bulbs, which consume about $17 \%$ of the energy required by a conventional bulb [10]. Due to the intrinsic variability in available wind energy, the solution

$18^{\text {th }}$ LACCEI International Multi-Conference for Engineering, Education, and Technology: "Engineering, Integration, and Alliances for a Sustainable Development" "Hemispheric Cooperation for Competitiveness and Prosperity on a Knowledge-Based Economy", 29-31 July 2020, Buenos Aires, Argentina. 3 
will include a battery bank to store enough energy for an estimated 12-hour daily operation.

The deliverable is a street lighting pole that runs $100 \%$ on renewable energy, becoming self-sustaining and functioning even with failures in the power grid. A complete change to Eolic generation on light poles represents reduction of approximately 100 million dollars annual cost of CELI allocated to municipalities. Once the deliverable is defined, more sections of the of the business plan were created and shown next.

A. Target Client - JET identified the primary customer as the 78 municipalities of Puerto Rico with a population of about 3.2 million citizens. The direct number of customers is comprised by the proprietaries of buildings, roads, residential complexes and other facilities that require pole illumination. These result in approximately 2,172 customers that are currently serviced by PREPA. These customers pay an average annual bill of $\$ 47,000$ to power streets and other public facilities.

B. Market Opportunities - There are about 550,000 light poles illuminating public roads and streets in Puerto Rico [9]. The majority of these (i.e., 95\%) are owned by the central government and municipalities on the island. The average annual cost per light pole is about $\$ 200$.

The customers' expectations are known in SE as Measures of Effectiveness (MOEs). With the intended customers as the municipalities of Puerto Rico some relevant MOE's in Table 2 include: (1) compliance with laws and regulations, (2) low cost, and (3) to be reliable and robust (capability to work under a variety of wind conditions).

Table 2 Measures of Effectiveness (MOE's).

\begin{tabular}{|c|c|}
\hline Measures of Effectiveness & Weight \\
\hline $\begin{array}{c}\text { Should be flexible to attach to any type of light } \\
\text { pole. }\end{array}$ & $9.7 \%$ \\
\hline $\begin{array}{c}\text { Should be maintained without much effort. } \\
\text { Shall last a long time. }\end{array}$ & $12.9 \%$ \\
\hline $\begin{array}{c}\text { Must be attractive (i.e., aesthetic). } \\
\text { (Environmental and Safety). }\end{array}$ & $12.9 \%$ \\
\hline $\begin{array}{c}\text { Shall be low cost (i.e., comparable to available } \\
\text { renewable technologies and payback periods). }\end{array}$ & $16.1 \%$ \\
\hline $\begin{array}{c}\text { Should be operated without significant effort. } \\
\text { Should be reliable and robust }\end{array}$ & $11.3 \%$ \\
\hline $\begin{array}{c}\text { Te.g., work under variety of wind conditions). } \\
\text { Total }\end{array}$ & $14.5 \%$ \\
\hline
\end{tabular}

The most relevant MOE's are: compliance with laws and regulations, reliability and costs. These are aligned with JET's mission and vision, and will be considered in all phases of development of the product. Fig. 5 shows a Pareto charts that states that these MOE's represent about $45 \%$ of the weight of the MOE's.

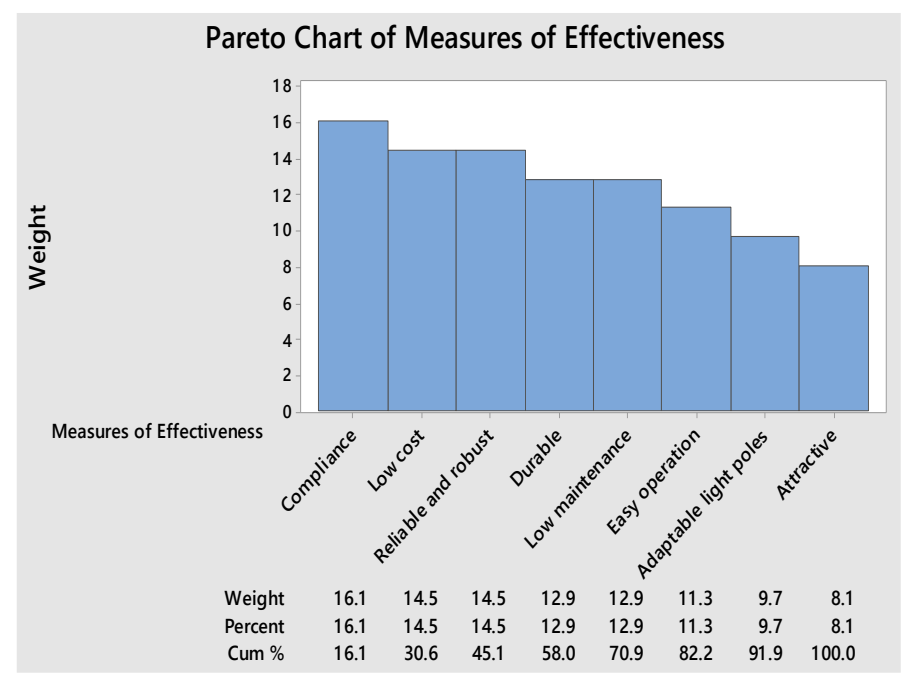

Fig. 5: MOE's prioritization analysis

Along with the definition of the Measures of Effectiveness, the team looked at various alternatives of Horizontal Axis (HAWTs) and Vertical Axis Wind Turbines (VAWTs). JET used the MOE's shown in Table 2 and the predefined weighting to select between a HAWT and a VAWT concept using a Pugh's Decision Matrix.

The Pugh's decision matrix is effective for comparing and selecting complex applications [11]. It compares one or more concepts versus a "baseline" by determining if the concept is better, equal or worse than the baseline (i.e., for a given criterion) by assigning +1 , " $\mathrm{S}$ "/ 0 , and -1 respectively. The different weights in the criteria allow to define their relative importance to the final product. A positive number in any of the concepts implies that it is better than the baseline. Table 3 shows the result of the Pugh Decision Matrix for the decision between a HAWT and a VAWT. In this case, the best alternative for this project is to use a VAWT configuration. 
Table 3 Pugh Decision Matrix for HAWT or VAWT

\begin{tabular}{|c|c|c|c|c|}
\hline $\begin{array}{l}\text { Select a wind turbine concept } \\
\text { for preliminary design } \\
(\text { Should be ...) }\end{array}$ & 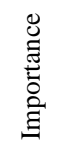 & 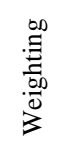 & 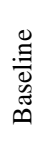 & 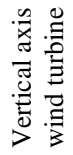 \\
\hline $\begin{array}{l}\text { Flexibility to attach to any } \\
\text { type of light pole }\end{array}$ & 5 & 9.7 & \multirow{8}{*}{$\underset{\Xi}{\Xi}$} & 0 \\
\hline Easy maintenance & 3 & 12.9 & & 1 \\
\hline Long lasting & 3 & 12.9 & & 0 \\
\hline Good aesthetic & 6 & 8.1 & & 1 \\
\hline $\begin{array}{l}\text { Compliance with existing } \\
\text { regulations }\end{array}$ & 1 & 16.1 & & 0 \\
\hline Low cost during lifetime & 2 & 14.5 & & -1 \\
\hline Easy operation & 4 & 11.3 & & 0 \\
\hline High Reliability & 2 & 14.5 & & 1 \\
\hline Total & 100 & & & 20.97 \\
\hline
\end{tabular}

\section{RISK ASSESSMENT}

The Preliminary Design stage requires the identification of potential risks affecting the design internally and externally. Once manufacturing of the turbine begins, all risks identified in this section must have been mitigated. The Cause and Effect Diagram shown in Fig. 5 was developed to identify risks involved pursuing wind turbine related business. Decreasing the occurrence of these risks can help businesses achieve better performance and growth. Additional risks will be further analyzed and corrected using techniques from the SE methodology.

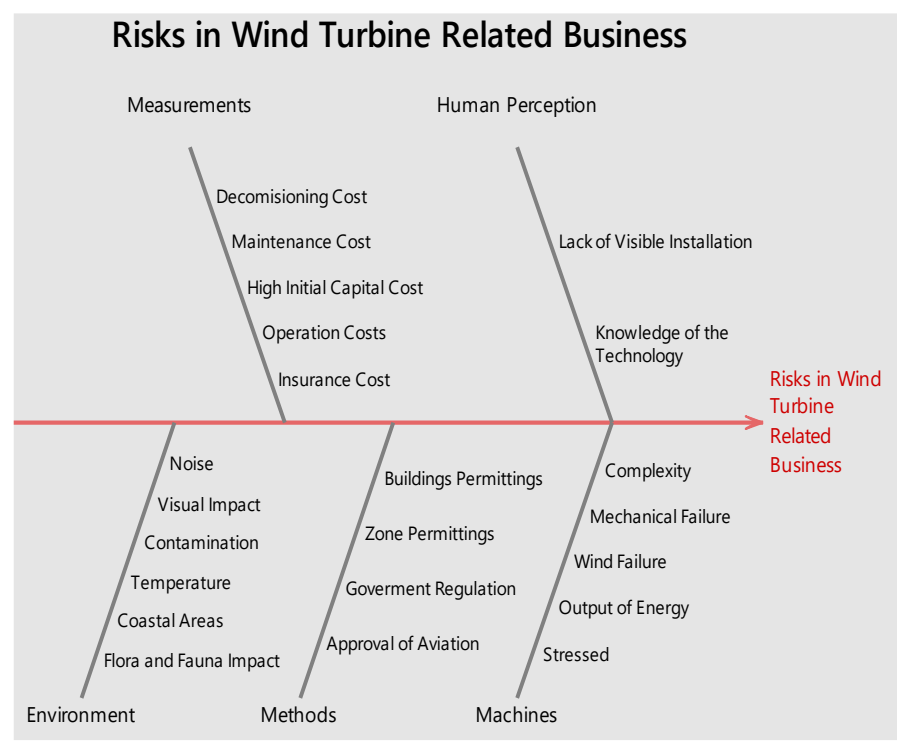

Fig. 5 Risk analysis of turbine related businesses

Some of the potential risks found include:

1. Adverse impacts to the environment due to installation of wind turbines in light poles.

2. State and federal regulations that can potentially make the development and production slower, time consuming and costly.

3. Degraded performance due to incorrect design of the wind turbine. This can be a significant factor to the success of the business, as defective product will end up rejected by customers.

4. Misconception that wind turbines are not a viable alternative to improve the existing light infrastructure problems. This can affect public interest in sampling the technology.

Additionally costs must be controlled and managed to successfully complete any project as small wind systems are generally more expensive than larger wind turbines relative to the amount of energy produced [12]. 


\section{CONCLUSIONS}

JET has identified public illumination as a significant area of opportunity to reduce the cost of public illumination, while increasing resiliency in case of power grid failures. This is the first business plan related to wind energy with small scale wind turbines, applied to public illumination in Puerto Rico and has shown that there is an opportunity, with multiple customers and significant economic impact. There are inherent risks in pursuing the development of this technology; these can be mitigated with a methodological design process.

The aftermath of hurricane Maria showed the need of alternative energy sources and to find alternatives for increasing robustness of these structures. For example, one of the two wind farms in the island had all its turbines destroyed after Maria [13]. Literature also recommends that the island also considers the development of micro-grids that include eolic energy applications, to increase resilience and decrease dependence on centralized power plants that could fail and leave the island without power in a natural disaster.

\section{NEXT STEPS}

An important future task is the distribution and collection of a survey for analyzing the viability of any outreach initiatives to increase knowledge in eolic energy. Additional evaluations regarding production capabilities and determining unit costs are also due. To refine the selection of future applications a decision approach using SPC and auxiliary decision rules and ranking could be used [14].

\section{REFERENCES}

[1] U. (2019). Puerto Rico Territory Energy Profile. Retrieved from https://www.eia.gov/state/print.php?sid=RQ.

[2] "Ley Núm. 82 de 2010 -Ley de Política Publica de DiversificaciónEnergética por Medio de la Energía Renovable Sostenible y Alterna en Puerto Rico", Lexjuris.com, 2019. [Online]. Available: http://www.lexjuris.com/lexlex/Leyes2010/lex12010082.htm. [Accessed: 13- Sep- 2014].

[3] R. Banuchi, "Buscan nueva tecnología para el alumbrado público", El Nuevo Día, 2019. [Online]. Available: https://www.elnuevodia.com/noticias/locales/nota/buscannuevatecnologi aparaelalumbradopublico-2004292/. [Accessed: 30- Jan- 2019].

[4] J. Marino, "PREPA profits on rising oil prices; faces financial obstacles to decreasing oil dependence" Caribbean Business, 24 April 2014. [3]

[5] U.S. Energy Information Administration - EIA - Independent Statistics and Analysis. (n.d.). Retrieved June 30, 2015, from http://www.eia.gov/electricity/monthly/epm_table_grapher.cfm?t=epmt_ 1_01_a

[6] McKeever, M. P. (2012). How to write a business plan. Berkeley, CA: Nolo.

[7] "Posterriqueño", Casapueblo.org, 2019. [Online]. Available: http://casapueblo.org/posterriqueno/index.html. [Accessed: 30- Jan2019].

[8] Ortiz, L. V. (2019, May 04). Puerto Rico announces deal to restructure power authority debt. Retrieved from https://www.reuters.com/article/ususa-puertorico-prepa/puerto-rico-announces-deal-to-restructure-powerauthority-debt-idUSKCN1SA026

[9] NASA systems engineering handbook, 1st ed. Books Express Pub., 2010.

[10] C. Marquez, "LED technology for public roads and streets to save $\$ 93$ million annually," Caribbean Business, 27 October 2014.

[11] Bailey, B. D., \& Lee, J. (2016). Decide and CONQUER. Quality Progress, 49(4), 30-37. Retrieved from http://librarylogin.suagm.edu:84/docview/1783899539?accountid=2886 7

[12] Gipe, P. (2004). Wind power: Renewable energy for home, farm, and business. White River Junction, VT: Chelsea Green.

[13] Kwasinski, F. Andrade, M. J. Castro-Sitiriche and E. O'Neill-Carrillo, "Hurricane Maria Effects on Puerto Rico Electric Power Infrastructure," in IEEE Power and Energy Technology Systems Journal, vol. 6, no. 1, pp. 85-94, March 2019. doi: 10.1109/JPETS.2019.2900293

[14] Duff, W. and Perez, J. (2014). "Statistical method to predict Graduation with Distinction at Colorado State University". 2014 Industrial and Systems Engineering Research Conference. IIE. 